\title{
Artificial Neural Networks for Prediction of Compressive Strength of Recycled Aggregate Concrete
}

\author{
Kirtikanta Sahoo, P. Sarkar, and Robin Davis P.
}

\begin{abstract}
Recycled coarse aggregates (RCA) are different in properties and composition than natural coarse aggregate. So it is very difficult to expect the same behaviour of RCA during mix design of concrete. This paper attempts to reveal the probable relationship between RCA properties and compressive strength of RCA concrete through regression analysis based on 20 numbers of available data collected from published literature. The parameters considered are water, cement, natural coarse aggregate, sand, RCA content in the design mix, saturated surface dried density, and maximum size of RCA. The regression analysis is run through SPSS software. It is observed that proposed relation predicts the compressive strength of RCA concrete that closely matches the experimental results.
\end{abstract}

Index Terms -Compressive strength, concrete, recycled coarse aggregate, regression analysis.

\section{INTRODUCTION}

Due to rapid urban development along with trade and industry activities, construction debris creates a problem for environment now a day. In construction waste concrete is the major source which makes disposal problem with more transportation cost. Such situation occurs in many countries like in India. As per Central Pollution Control Board it has been assessed that the solid waste generation is about 48 million tonnes per annum of which $25 \%$ are from the construction industry. Simultaneously due to rapid construction early exhaustion of natural aggregates (fine and coarse) occurs and put the impact on the environment.

Since the last two decades, many researchers have prepared use of various methods to predict the properties of concrete prepared by different mix proportions. Among these methods, methods based on regression analysis are quite popular. The main advantage of this technique, it is totally a mathematical regression process. The intend of this paper is to account the results of a study to evaluate whether or not the compressive strength of concrete made with different types and sources of recycled aggregates can be predicted by regression analysis.

Kirtikanta Sahoo, Ph.D Scholar National Institute of Technology Rourkela Odisha,769008, India

Pradip Sarkar, Associate Professor National Institute of Technology Rourkela Odisha,769008, India

Robin Davis P., Assistant Professor National Institute of Technology Rourkela Odisha,769008, India
For this data sets are collected and compared with each other by linear regression analysis. So in the present work for regression analysis (Linear Regression System) IBMSPSS software is used. In this analysis the variables are divided into two categories such as dependent and independent variables. By considering these variables a mathematical formulation is formulated. The constructed model had 9 input parameters and one output parameter. The predicted results were compared with the experimentally determined results.

\section{RECYCLED AGGREGATE}

The common difference between RCA and natural aggregate (NA) is that RCA is adhered with mortar from the parent concrete which is about $20-30 \%$ of the total volume. This is normally depends on the properties of the original concrete from which the RCA is obtained and the making process of the RCA. RCA has properties like more flaky in shape, lower bulk and SSD specific densities, higher water absorption, inferior strength, presence of contaminants (e.g. ceramic) and lower resistance to mechanical and chemical actions when compared with NA and known as the primary features. Parameters like specific density, water absorption, porosity, percentage of elongated particles, fineness modulus, strength indices $(10 \%$ fines value, crushing value, impact value, and Los Angeles abrasion) and impurity content are often adopted to evaluate the properties of the RCA.

It is observed that the concrete made from RCA often substandard to those concrete prepared with only NA due to the high water absorption and low density of RCA. Normally RCA are used as recycled aggregate because recycled fine aggregate has more water absorption quality. So this paper discussed the use of recycled coarse aggregate in new concrete. Also it is examined that the strength of RCA concrete depends on the replacement ratio of RCA. It is reported that with the increment in the ratio of replacement RAC the strength simultaneously decreases.

From the previous literatures, the mechanical properties of RAC concrete are in general low-grade to those of NAC concrete; mainly because of the presence of old cement paste. To sustain the same workability without the use of chemical admixtures, RAC requires more water to maintain workability than conventional concrete, which affects the quality and strength of the concrete, resulting in lower concrete strength. On the basis of literature survey it is found that the attached mortar content was inversely proportional to the size of the RCA, and the higher amount attached mortar would direct to lower density, and the trends were similar for values of water absorption, Los Angeles abrasion and sulphate content of the RCA. 


\section{REGRESSION ANALYSIS}

As previously describe that this paper aims to produce a mathematical equation, by using this we easily predict the relation between the compressive strength RCA concrete and RCA properties. In this present work, an efficient technique is used for forming a mathematical equation. So mathematics like Statistics Data Editor System (SPSS) is proposed for prediction of the relation.

The term "Regression" originates from the 14th century, where it had a biological mean in gas "the act of going back". It was first adapted to a more general statistical context by the well-known statisticians Udny Yule and Karl Pearson. Regression is a generic term for all methods attempting to fit a model to observed data in order to quantify the relationship between two groups of variables. The fitted model may then be used either to merely describe the relationship between the two groups of variables, or to predict new values. The first widely studied form of regression analysis has been linear regression, due to the simplicity of the model and the statistical properties of the estimators. Linear regression is usually used for the purpose of hypothesis testing or for the purpose of prediction and forecasting. Many statistical methods and techniques have emerged from its study and one of them is the simultaneous confidence band. This paper provides a general review of linear regression and presents some preliminary results necessary for the construction and comparison of simultaneous confidence bands.

\section{A. Linear Regression Analysis}

A common problem in experimental science is to observe how some sets of variables affect others. Some relations are deterministic and easy to interpret, others are too complicated to understanding or describe in simple terms, that possibly having a random component. In the present study, by using relatively simple empirical methods we estimated these actual relationships by simple functions or random processes. Among all the methods used for calculating such complex relationships, linear regression possibly is the most useful. In this methodology, it is necessary to assume a functional, parametric relationship between the variables in question, and also unknown parameters which are to be estimated from the available data. Two sets of variables can be well-known at this stage such as Predictor variables and response variables. Predictors variables are those that can either be set to controlled or else take values that can be observed without any error. Our objective is to discover that how changes occurs in the predictor variables that affect the values of the response variables.

Linear regression analysis means it is a statistical technique used to model data comprising of a dependent random variable and one or more independent variables, so as to evaluate the relationship between the dependent variable and the independent variables. In statistics, simple linear regression is the least squares estimator of a linear regression model with a single helpful variable. In other words, simple linear regression fits a straight line through the set of $n$ points in such a way that makes the sum of squared residuals of the model (that is, vertical distances between the points of the data set and the fitted line) as small as possible.

\section{EXPERIMENTAL PROGRAM}

\section{B. Input Parameters}

For regression analysis total 9 parameters are taken into consideration. These are listed above Table1 respectively.

TABLE 1

INPUTS AND OUTPUTS FOR THE ANALYSIS

\begin{tabular}{|c|c|c|}
\hline Parameters & Minimum & Maximum \\
\hline $\mathrm{W}(\mathrm{Kg} / \mathrm{m} 3)$ & 132 & 241 \\
\hline $\mathrm{C}(\mathrm{Kg} / \mathrm{m} 3)$ & 275 & 501 \\
\hline $\mathrm{S}(\mathrm{Kg} / \mathrm{m} 3)$ & 467 & 868 \\
\hline $\mathrm{NA} \mathrm{Kg} / \mathrm{m} 3)$ & 226 & 1301 \\
\hline $\mathrm{RA} \mathrm{Kg} / \mathrm{m} 3)$ & 422.2 & 1196 \\
\hline $\mathrm{DCA}(\mathrm{mm})$ & 5 & 31.5 \\
\hline $\mathrm{W} / \mathrm{C}$ & 0.43 & 0.5 \\
\hline $\mathrm{Wm}(\%)$ & 0.4 & 9.25 \\
\hline Fcu(Mpa $)$ & 27 & 54.8 \\
\hline
\end{tabular}

TABLE II

INGREDIENTS OF MIX COLLECTED FROM AVAILABLE LITERATURE

\begin{tabular}{|c|c|c|c|c|c|c|c|}
\hline Ref. & $\begin{array}{c}\text { Cemen } \\
\mathrm{t} \\
\left(\mathrm{kg} / \mathrm{m}^{3}\right. \\
)\end{array}$ & $\begin{array}{c}\text { Water } \\
\left(\mathrm{kg} / \mathrm{m}^{3}\right. \\
)\end{array}$ & $\mathrm{W} / \mathrm{C}$ & $\begin{array}{c}\text { Sand } \\
\left(\mathrm{kg} / \mathrm{m}^{3}\right)\end{array}$ & $\begin{array}{c}\text { Natural } \\
\text { Aggregate } \\
\left(\mathrm{kg} / \mathrm{m}^{3}\right)\end{array}$ & $\begin{array}{l}\text { Recycled } \\
\text { Aggregat } \\
\text { e }\left(\mathrm{kg} / \mathrm{m}^{3}\right)\end{array}$ & $\begin{array}{c}\text { Size } \\
\text { of } \\
\text { CA } \\
(\mathrm{mm}) \\
\end{array}$ \\
\hline 1 & 379 & 190 & - & 623 & 1237 & 1171 & $\begin{array}{l}10, \\
20\end{array}$ \\
\hline 2 & 410 & 225 & - & 642 & 1048 & 1017 & $\begin{array}{l}10, \\
20\end{array}$ \\
\hline 3 & 392 & 132 & - & 823 & 960 & 888 & 25 \\
\hline 4 & 275 & 179 & - & 868 & 226 & 830 & - \\
\hline 5 & 401 & - & 0.43 & 574 & 1261 & 1128 & - \\
\hline 6 & $\begin{array}{c}390, \\
501\end{array}$ & 185 & 0.47 & $\begin{array}{c}558, \\
467\end{array}$ & 1301 & 1109 & $\begin{array}{c}5, \\
31.5\end{array}$ \\
\hline 7 & 380 & 190 & 0.5 & 714 & 882.2 & 874.04 & - \\
\hline 8 & 353 & $\begin{array}{l}214, \\
241\end{array}$ & - & $\begin{array}{c}667, \\
625\end{array}$ & 1080 & 990 & $\begin{array}{l}10, \\
20\end{array}$ \\
\hline 9 & 325 & - & 0.5 & $\begin{array}{l}710, \\
710\end{array}$ & 346.5 & 422.2 & - \\
\hline 10 & 395 & 198 & - & 563 & 1196 & 1196 & - \\
\hline 11 & 380 & 190 & 0.5 & 687 & 1145 & 955 & $\begin{array}{l}10, \\
20\end{array}$ \\
\hline
\end{tabular}


TABLE III

PROPERTIES OF THE INGREDIENTS OF MIX COLLECTED FROM AVAILABLE LITERATURE

\begin{tabular}{|c|c|c|c|c|c|c|}
\hline \multirow[b]{2}{*}{ Ref. } & \multicolumn{2}{|c|}{$\begin{array}{c}\text { Water absorption } \\
(\%)\end{array}$} & \multirow[b]{2}{*}{$\begin{array}{l}\text { Char. } \\
\text { Strength } \\
\text { (MPa) }\end{array}$} & \multicolumn{3}{|c|}{ Oven dried density $(\mathrm{kg} / \mathrm{m} 3)$} \\
\hline & $\begin{array}{c}\text { Natural } \\
\text { Aggreg } \\
\text { ate }\end{array}$ & $\begin{array}{l}\text { Recycl } \\
\text { ed } \\
\text { Aggreg } \\
\text { ate }\end{array}$ & & $\begin{array}{c}\text { Natural } \\
\text { aggregate }\end{array}$ & $\begin{array}{c}\text { Natural } \\
\text { recycled } \\
\text { aggregat } \\
\mathrm{e}\end{array}$ & $\begin{array}{c}\text { Natural } \\
\text { fine } \\
\text { aggregat } \\
\mathrm{e}\end{array}$ \\
\hline 1 & 1.25 & 8.82 & $\begin{array}{l}41.5, \\
32.6\end{array}$ & 2.62 & 2.41 & 2.39 \\
\hline 2 & 1.12 & 4.26 & $\begin{array}{l}48.6, \\
36.8\end{array}$ & 2.62 & 2.49 & - \\
\hline 3 & 0.69 & 2.99 & 27 & - & - & - \\
\hline 4 & 1.8 & 5.3 & $\begin{array}{l}51.3, \\
42.7\end{array}$ & 2.51 & - & 2.32 \\
\hline 5 & 1.13 & 3.1 & $\begin{array}{l}49.5, \\
40.8\end{array}$ & 1.58 & 1.62 & 1.34 \\
\hline 6 & 0.4 & 9.25 & $\begin{array}{l}35.6, \\
28.7\end{array}$ & 1.45 & - & 1.29 \\
\hline 7 & 0.98 & 5.19 & $\begin{array}{l}54.8, \\
45.2\end{array}$ & 2.65 & - & 2.34 \\
\hline 8 & 1.25 & 7.56 & $\begin{array}{l}48.3, \\
46.8\end{array}$ & 2.62 & - & 2.33 \\
\hline 9 & - & - & $\begin{array}{l}29, \\
28\end{array}$ & & - & - \\
\hline 10 & - & - & - & 1.26 & - & 1.41 \\
\hline 11 & 0.9 & 7.6 & $\begin{array}{l}54.3, \\
42.6\end{array}$ & 2.61 & 2.6 & 2.34 \\
\hline
\end{tabular}

\section{Concrete parameters}

The concrete constituents in a concrete mix such as amount of water, W/C ratio, cement, sand, natural coarse aggregate, recycled coarse aggregate has a effects on concrete for its strength. Simultaneously the quality of coarse aggregate such as maximum particle size, water absorption, and density also affects the strength of the concrete. The ingredients of mix collected from available literature along with their properties are tabulated in the Table $2 \& 3$ respectively.

\section{Output parameters}

Objective of mix design is to get the target compressive strength after 28 days successive curing. So in this paper 28 days compressive strength is taken only output value. Because all the parameters properties directly or indirectly influence the compressive strength of the concrete.

\section{E. Regression analysis}

For regression analysis 9 number parameters are taken into consideration from 20 literatures and try to correlate the relation in between them to get the output in terms of 28 days compressive strength of the RCA concrete.

\section{RESULTS}

By using SPSS software, mathematical model is now formulated. From the regression analysis an empirical formulation is formulated. These equations shows the relation between 28 days compressive strength, water content, W/C, cement, RCA content, density, NCA content, maximum size of NCA and RCA respectively. From regression analysis the obtained standard error between actual and compressive strength of the concrete provided in the Table $4 \& 5$ respectively. It is clearly seen that from the graph, it's plotted between the predicted 28 days compressive strength verses actual compressive strength for both RCA concrete as well as natural aggregate concrete.

TABLE IV

NATURAL AGGREGATE CONCRETE

\begin{tabular}{|c|c|c|c|}
\hline \multicolumn{1}{|c|}{ NATURAL AGGREGATE CONCRETE } \\
\hline 42 & Predicted & Residuals & $\begin{array}{c}\text { Std Error } \\
\text { Prediction }\end{array}$ \\
\hline 49 & 43.59 & -1.59 & 4.19 \\
\hline 27 & 49.75 & -0.75 & 4.34 \\
\hline 51 & 27.53 & -0.53 & 4.43 \\
\hline 49 & 48.86 & 2.14 & 4.13 \\
\hline 36 & 49.21 & -0.21 & 4.44 \\
\hline 55 & 36.12 & -0.12 & 4.44 \\
\hline 48 & 53.10 & 1.90 & 3.36 \\
\hline 29 & 49.83 & -1.83 & 4.02 \\
\hline 49 & 31.70 & -2.70 & 4.01 \\
\hline 36 & 48.88 & 0.12 & 4.44 \\
\hline 54 & 31.88 & 4.12 & 3.33 \\
\hline
\end{tabular}

TABLE V

RECYCLED COARSE AGGREGATE

\begin{tabular}{|c|c|c|c|}
\hline Fcu actual & Predicted & Residuals & $\begin{array}{c}\text { Std Error } \\
\text { Prediction }\end{array}$ \\
\hline 32.6 & 31.53 & 1.07 & 1.53 \\
\hline 36.8 & 37.72 & -0.92 & 1.57 \\
\hline 36.5 & 36.83 & -0.33 & 1.48 \\
\hline 42.6 & 43.08 & -0.48 & 1.67 \\
\hline 40.8 & 41.51 & -0.71 & 1.51 \\
\hline 28.7 & 28.60 & 0.10 & 1.67 \\
\hline 45.25 & 43.88 & 1.37 & 1.39 \\
\hline 46.8 & 46.50 & 0.30 & 1.55 \\
\hline 38 & 38.20 & -0.20 & 1.69 \\
\hline 48.51 & 47.79 & 0.72 & 1.58 \\
\hline 46 & 46.24 & -0.24 & 1.66 \\
\hline 42.65 & 43.31 & -0.66 & 1.40 \\
\hline
\end{tabular}

In this case, it is found that in Fig $1 \& 2$, both predicted vs. actual 28 days compressive strength agrees perfectly and also gives a satisfactory result along appropriately with determination/ Roughness coefficient is $\mathrm{R}^{2}=0.96$ and $\mathrm{R}^{2}=0.98$ respectively.

Therefore from the above figure it is clearly concluded that the present model gives a better 28 days compressive strength result which proves to adequacy of present developed model. 

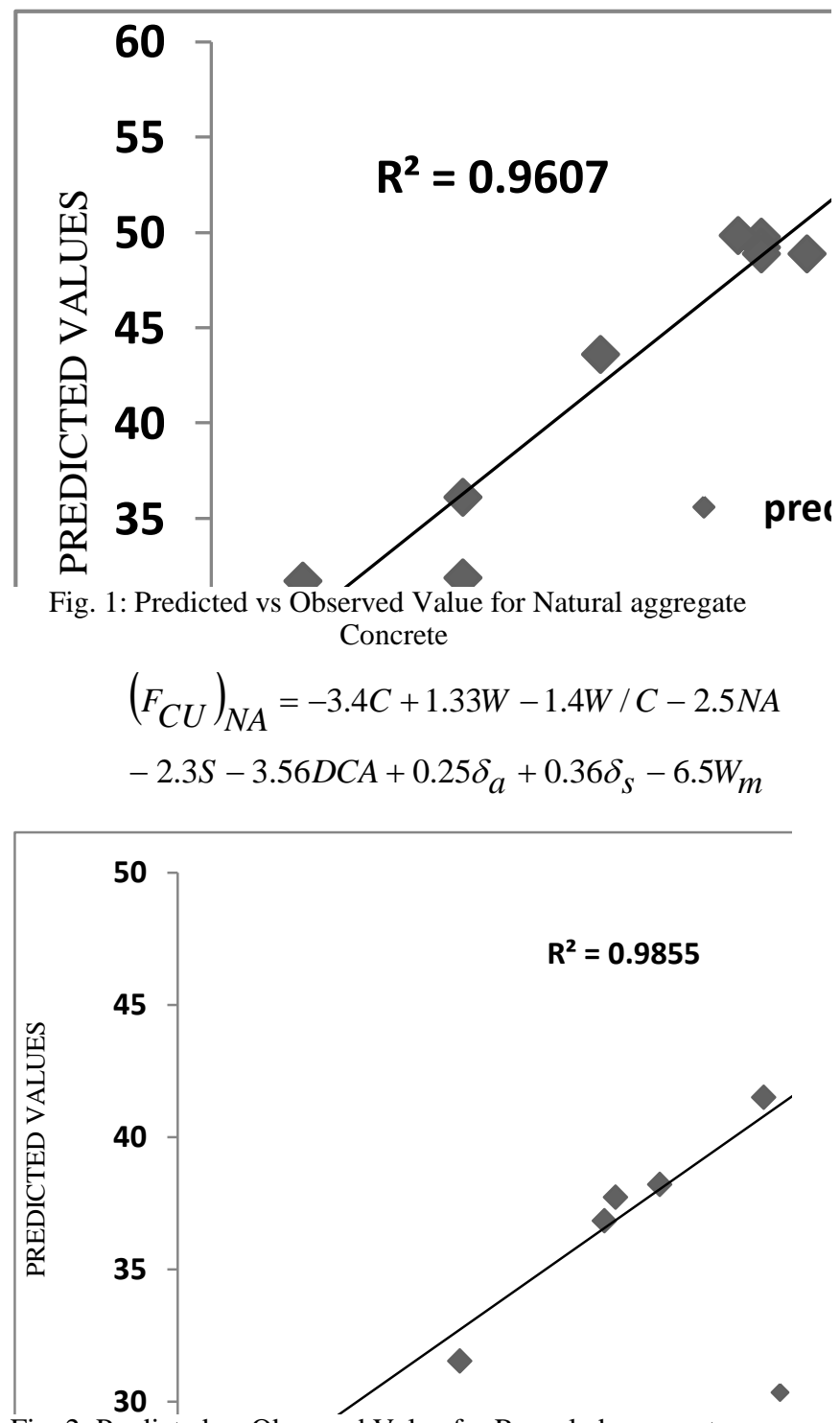

Fig. 2: Predicted vs Observed Value for Recycled aggregate Concrete

$$
\begin{aligned}
& \left(F_{C U}\right)_{R C A}=-1.24 C+0.22 W-1.1 W / C+0.9 R A \\
& -0.28 S-0.52 D C A-1.05 \delta_{b}+0.32 \delta_{s}-0.26 W_{m}
\end{aligned}
$$

$C$ : ordinary Portland cement; $W$ : water; $W / C$ : watercement ratio; $R A$ : recycled aggregate; $S$ : sand; $D C A$ : maximum size of coarse aggregate; $\delta a$ : oven dried density of NA; NA: natural aggregate; $\delta b$ : oven dried density of $R A ; \delta s$ : oven dried density of Sand; $W m$ : water absorption of coarse aggregate; Fcu: 28-day compressive strength.

\section{VI.CONCLUSIONS}

The salient conclusions from the present study are as follows:

- The above two equations formulated for the prediction of compressive strength of the concrete has a high capacity for prediction.

- Oven dry density, water absorption and size mainly govern the analysis.

- The regression analysis still requires more parameters for improving the advance exploration.

\section{REFERENCES}

[1] Won-Chang Choi, Hyun-Do Yun., "Long-term deflection and flexural behaviour of reinforced concrete beams with recycled aggregate". Materials and Design, 51, pp.742-750, 2013.

http://dx.doi.org/10.1016/j.matdes.2013.04.044

[2] Vivian W.Y. Tam, et al., "Microstructural analysis of recycled aggregate concrete produced from two-stage mixing approach". Cement and Concrete Research, 35, pp.1195-1203, 2005.

http://dx.doi.org/10.1016/j.cemconres.2004.10.025

[3] Salomon M. Levy, Paulo Helene., "Durability of recycled aggregates concrete: a safe way to sustainable development". Cement and Concrete Research, 34, pp.1975-1980, 2004.

http://dx.doi.org/10.1016/j.cemconres.2004.02.009

[4] F.T. Olorunsogo, N. Padayachee., "Performance of recycled aggregate concrete monitored by durability indexes". Cement and Concrete Research, 32, pp.179-185, 2002. http://dx.doi.org/10.1016/S0008-8846(01)00653-6

[5] Benito Mas, Antoni Cladera,et.al., " Influence of the amount of mixed recycled aggregates on the properties of concrete for non-structural use". Construction and Building Materials, 27, pp.612-622, 2012. http://dx.doi.org/10.1016/j.conbuildmat.2011.06.073

[6] Zoran Jure Grdic, et.al., "Properties of self-compacting concrete prepared with coarse recycled concrete aggregate". Construction and Building Materials, 24, pp.1129-1133, 2010.

http://dx.doi.org/10.1016/j.conbuildmat.2009.12.029

[7] S.C. Kou, C.S. Poon., "Properties of self-compacting concrete prepared with coarse and fine recycled concrete aggregates". Cement \& Concrete Composites, 31, pp.622-627, 2009.

http://dx.doi.org/10.1016/j.cemconcomp.2009.06.005

[8] Shi-Cong Kou, et.al.,"Influence of recycled aggregates on long term mechanical properties and pore size distribution of concrete". Cement \& Concrete Composites, 33, pp.286-291, 2011.

http://dx.doi.org/10.1016/j.cemconcomp.2010.10.003

[9] Benito Mas, et.al., "Concrete with mixed recycled aggregates: Influence of the type of ement". Construction and Building Materials, 34, pp.430-441, 2012.

http://dx.doi.org/10.1016/j.conbuildmat.2012.02.092

[10] C.S. Poon, et.al., "Influence of moisture states of natural and recycled aggregates on the slump and compressive strength of concrete". Cement and Concrete Research, 34, pp.31-36, 2004.

http://dx.doi.org/10.1016/S0008-8846(03)00186-8

[11] M. Etxeberria, et.al., "Influence of amount of recycled coarse aggregates and production process on properties of recycled aggregate concrete". Cement and Concrete research, 37, pp.735-742, 2007. http://dx.doi.org/10.1016/j.cemconres.2007.02.002

[12] Patrícia S. Lovato, et.al., "Modeling of mechanical properties and durability of recycled aggregate concretes". construction and Building Materials, 26, pp. 437-447, 2012.

[13] Yeong-Nain Sheen, et.al., "Assessment on the engineering properties of ready-mixed concrete using recycled aggregate". Construction and Building Materials, 45, pp.298-305, 2013.

http://dx.doi.org/10.1016/j.conbuildmat.2013.03.072

[14] Won-Chang Choi, Hyun-Do Yun., "Compressive behaviour of reinforced concrete columns with recycled aggregate under uniaxial loading”. Engineering structures, 41 pp.285-293, 2012. http://dx.doi.org/10.1016/j.engstruct.2012.03.037

[15] Z.H. Duan, S.C. Kou, C.S. Poon., "Prediction of compressive strength of recycled aggregate concrete using artificial neural networks". Construction and Building Materials, 40, pp.1200-1206, 2013. http://dx.doi.org/10.1016/j.conbuildmat.2012.04.063

[16] M. Chakradhara Rao, et.al., "Behaviour of recycled aggregate concrete under drop weight impact load". Construction and Building Materials, 25, pp.69-80, 2011. http://dx.doi.org/10.1016/j.conbuildmat.2010.06.055

[17] S.Manzi, et.al., "Short and long-term behavior of structural concrete with recycled concrete aggregate". Cement \& Concrete composites, 37 pp.312-318, 2013. 
http://dx.doi.org/10.1016/j.cemconcomp.2013.01.003

[18] C. Thomas, et.al., "Durability of recycled aggregate concrete." Construction and Building materials, 40, pp.1054-1065, 2013.

http://dx.doi.org/10.1016/j.conbuildmat.2012.11.106

[19] A.K. Padmini, , et.al., "Influence of parent concrete on the properties of recycled aggregate concrete". Construction and Building Materials, 23, pp.829-836, 2009.

http://dx.doi.org/10.1016/j.conbuildmat.2008.03.006

[20] Akash Rao, et.al., "Use of aggregates from recycled construction and demolition waste in concrete resources", Conservation and Recycling, 50, pp. 71-81, 2007.

http://dx.doi.org/10.1016/j.resconrec.2006.05.010

[21] Dash Saine S., "Stage-Discharge Modeling for Meandering Channel". Thesis submitted to the National Institute of Technology, Rourkela, 2013. 